\title{
Organization of outdoor practice of students
}

\author{
Nadezhda Sotnikova* \\ Don State Technical University, 344003, Rostov-on-Don, Russia
}

\begin{abstract}
In this article we consider ways of solving the problem of lacking practical experience in drawing and painting among the students of architecture departments. We propose a solution to this problem through creation of teaching methods aimed to develop a perception of of nature, compositional and technical skills and abilities. We study the principles of the approach to the plein air practice working program of the leading architectural universities in Russia, and also compare and analyze two approaches to the program: an interdisciplinary approach based on the relationship of architecture with the visual arts - drawing and studying architectural monuments and holding a plein air in the form of master classes by professional artists, with an emphasis on techniques and technologies of work in the plein air. Revealing the methodological features of building a program for mastering the universal and general professional competencies of an architect and designer: acquaintance with the monuments of architectural heritage, a creative research approach to the object of study, the development of compositional thinking and the basics of linear constructive drawing, the development of graphic techniques necessary for working on sketches of projects. Recommendations are given for the development of tasks for plein air practice for students of architecture, reconstruction, urban planning and design departments.
\end{abstract}

\section{Introduction}

Drawing and painting are special subjects required in the training of an architect and designer. Due to the small number of hours of independent work, the time to complete sketches is not enough to master the related skills. This negatively affects the development of the material of educational plein air practice. Working at plein air implies a lot of independence. The student must choose the object for sketching, find an interesting angle, think over the composition, draw an image. This corresponds to the performance of a professional artist when the composition of the project is thought out and solved by the author, who performs the whole range of tasks for its implementation. From this perspective, it is supposed to consider what tasks and in what sequence form the corresponding skills.

What contributes to the creative development of an architect and designer? The scientific article by Zakharova, N., Vlasova, I., Kartavtseva, O. "Technologies of tutorial assistance in the visual activity distance education for the bachelors-designers" [1] examines the development of a creative personality with the help of an all-round artistic and cultural development of students in collaboration with the teacher. The article by Zakharova, N.,

*Corresponding author: spu-57.4@donstu.ru 
Vlasova, I. "Technological initiative for the roadmap implementation for the bachelorsdesigners' creative development in art" [2], considered a personality-oriented and practiceoriented approach to the organization of the educational process. The article by Vlasova, I., Ushanyova, Y., Pisarenko, S. "Professional competencies formation in the field of aesthetic artwork evaluation" [3] examines the developmental possibilities of the methodology for students' independent search for works of fine art. In articles by Burovkina L.A., Koreshkov V.V., Prishchepa A.A. "The problem of preparing future designers" [4] and Prishchepa A., Maidibor O. "The value of ancient architecture for an educational program of masters of architectural space design" [5] discusses educational opportunities for studying the history of architecture, archeology, cultural history, local history, arts and crafts in the formation of the image of an architectural project. The article by Asu Besgena, Nilgun Kuloglub, Sara Fathalizadehalemdaric "Teaching / Learning Strategies through Art: Art and Basic Design Education" [6] is devoted to the development of visual thinking in designers through comprehension of the elements and principles of art. Asu Besgen's article "Teaching / Learning Strategies through Art: Painting and Basic Design Education" [7] examines the relationship between painting and architecture, the study of compositional schemes using examples of works of fine art, the study of architectural monuments in which painting is a spatial element. Peter O Adewale, Olasunmbo Bolanle Adhuze in "Entry qualifications and academic performance of architecture students in Nigerian Polytechnics: Are the admission requirements still relevant?» [8] consider the situation in the architectural education of Nigeria, where the basis of the program is mathematics and physics and prove that there is no direct dependence of the success of graduates on the development of these subjects and it is necessary to develop graphic skills. In article by Ana Torres, Juan Serra, Jorge Llopis, Ángela García, Nacho Cabodevilla "The Need and Experience Of Drawing With Ingeniuty. An Analysis of the Graphic Practice in Architectural Education" [9] discuss the importance of exploratory sketches and constant drawing exercises. Mohammadjavad Mahdavinejada, Raha Bahtooeia, Seyyed Mohammadmahdi Hosseinikiab, Mahsa Bagheric, Ayoob Aliniaye Motlaghd, Fatemeh Farhat "Aesthetics and Architectural Education and Learning Process" [10] raise a question of the relationship between aesthetics and architecture in teaching.

Melda Arca Yalçın, Mine Ulusoy in the article "Personal and professional attitudes of architecture students" [11] conduct a study of students' opinions about the most demanded professional qualities. Adina Palea, Georgeta Ciobanu, Annamaria Kilyeni in "Educational skills in training landscape architecture students: developing communication skills" [12] consider the development of communication skills necessary for integration in the labor market. Designers Denis Weil Matt Mayfield in "Tomorrow's Critical Design Competencies: Building a Course System for the 21st Century" [13] discusses what are the most important competencies for a designer.

Discussion Gunnar Swanson "Educating the Designer of 2025" stands out in foreign scientific articles [14]. There is an interesting statement that broad education does not guarantee high qualifications of the student, and most importantly, the development of curiosity and practical project activities; there is no one right way for everyone, and the variety of methods is more useful. First of all, it is necessary to encourage the student's interest in learning, and thinking is best developed through the creation of real projects. The author recommends teaching students to teamwork systems thinking and acquainting them with large-scale projects. Hacer Mutlu Danaci in his article "Creativity and knowledge in architectural education" [15] also raises the question of the application of theoretical knowledge in practice and points out the difficulties caused by the insufficient number of seminars and practices.

The lack of practical experience in drawing and painting can be compensated for by developing teaching methods aimed at developing the perception of nature in the plein air. The object of the research is to consider the process of formation to skills and abilities of 
work in the plein air to increase its effectiveness. The practice was held for first- and secondyear students in the direction of "Architecture", "Urban planning", "Reconstruction and restoration of architectural heritage" and "Design" of the Don State Technical University.

- This article discusses the types of building work program for plein air practice in architectural universities in Russia.

- The connection between the plein air work program and the professional competencies of students in the areas of architecture and design has been established.

- Two different programs of plein air analysis of the creative achievements of students are considered.

\section{Materials and methods}

The program of artistic practice in various architectural universities in Russia is based on several principles. One of them examines the step-by-step study of the techniques and methods of constructing a graphic image from simple to complex by students, the study of compositional techniques used both in graphics and in design. Another type of program provides for the study with the help of graphics of types of architectural objects: industrial and civil buildings - housing, cultural, and religious buildings - analysis of the architectural concept of the object, identification of the compositional structure of the monument. Another type of building program of artistic practice involves its connection with the design art history: drawing architectural monuments of a certain period, identifying compositional and stylistic features of the architecture.

\subsection{The place of the plein air practice is the Crimean Peninsula 2019}

Excursions - Sevastopol, Balaklava, Bakhchisarai Historical, Cultural and Archaeological Museum-Reserve, State Historical and Archaeological Museum-Reserve Tauric Chersonesos. The practice program was based on an interdisciplinary approach - the relationship between architecture and the visual arts. The tasks were set: a study of the monuments of the architectural heritage of Russia through the comprehension of their architectural forms in drawing and painting; the complex impact of various plastic arts on the development of compositional skills of future architects, the development of graphic skills and color perception.

The students showed interest in the excursions, the sketches turned out to be expressive and varied in technique. In drawing the Bakhchisarai Palace, the task was to display the variety of decorative finishes without splitting the composition. To emphasize the organizing role of monumental and decorative art in the architectural image of the object, the expressiveness of the ornament, the beauty of lines and silhouette, and the rhythms of color spots. The sketches turned out to be interesting, in the sketches the characteristic color of the monument was successfully displayed. Many have carefully and enthusiastically worked on the decorative elements. When depicting the embankment of Balaklava, the task was to depict an open space, a multifaceted composition. Despite the variety of colors, the works turned out to be expressive, although they caused difficulties at the stage of generalization. Independent sketches of boats, yachts, and motor ships turned out to be interesting and expressive. There was a review of the preparatory material, then a search for ideas for the final composition.

\subsection{The place of the plein air practice is the village of Divnomorskoye 2020}


The excursions were conducted in the Gelendzhik Museum of History and Local Lore, dolmens on the Zhane River, Lake Abrau in the village of Abrau-Dyurso. The practice was carried out in the form of master classes by the masters of the Russian Academy of Arts. Students took part in exhibition activities. Objectives of the practice: acquaintance with the work of outstanding figures of culture and art; training in drawing techniques under the guidance of masters; study of related areas necessary for an architect in his future professional activity.

The master classes were held on the following topics: "Study of a seascape", "City landscape", "Study of a city street", "Sunset at the sea", "Mountain landscape". The artists showed the methods of drawing large planes with local colour, the technique of multilayer watercolor painting. In addition, they talked about the correct conduct of the work, the tonal gradation of objects. The one of the master classes was devoted to the use of a limited palette of colors in painting and the meaning of tone. Another master class was devoted to the use of an extended palette of colors, or, as it is also called, multicolor. Sketches of many students turned out to be successful, color was harmoniously found, lighting was rendered correctly. The fast pace of work ensured freshness of color and general expressiveness of the work. Minor issues were related to the quality of the watercolor paper and brushes. There were difficulties with tonal analysis and identification of spatial plans, a fear of color - sluggish tone relationships.

There were many other master classes devoted to graphic sketches in different techniques, quick sketches for attention, memory and logical thinking. By that way, the speed of perception and drawing is developed, since a short time does not allow one to be distracted by details and it is necessary to grasp only the main thing - shape, design, volume, plasticity, silhouette.

\section{Results}

The following Table 1 gives the comparison of the two places of the plein air practice.

Table 1. The sequence of the formation of graphic skills.

\begin{tabular}{|l|l|}
\hline The practice base - Crimean Peninsula & The practice base - settlement Divnomorskoe \\
\hline $\begin{array}{l}\text { Knowledge about monuments of } \\
\text { architectural heritage, their history, and } \\
\text { features of the artistic style and planning }\end{array}$ & $\begin{array}{l}\text { The skill of determining the local color of an } \\
\text { object, the principle of working with large } \\
\text { color ratios }\end{array}$ \\
\hline Compositional skills have improved. & $\begin{array}{l}\text { The skill of determining the general tone in } \\
\text { the study has improved. }\end{array}$ \\
\hline $\begin{array}{l}\text { Mastered work in different graphic } \\
\text { techniques }\end{array}$ & $\begin{array}{l}\text { The skill of analyzing tonal relationships } \\
\text { have been formed }\end{array}$ \\
\hline $\begin{array}{l}\text { The skill of comparing and analyzing tonal } \\
\text { relationships, which has a positive effect on } \\
\text { the transfer of spatial plans in sketches and } \\
\text { sketches }\end{array}$ & $\begin{array}{l}\text { The skill of comparing and analyzing color } \\
\text { relationships has improved. Achieved great } \\
\text { expressiveness in the transmission of the } \\
\text { states of nature. }\end{array}$ \\
\hline Improved the light perception & Analysis of spatial plans \\
\hline $\begin{array}{l}\text { Skills of working in a limited and } \\
\text { multicolored palette. }\end{array}$ & $\begin{array}{l}\text { Compositional integrity in sketch and study } \\
\text { solutions }\end{array}$ \\
\hline $\begin{array}{l}\text { Selection of compositional means, selection } \\
\text { of analogs, bringing the work to completion. }\end{array}$ & $\begin{array}{l}\text { Skills in working with various graphic } \\
\text { materials, speed of perception, and drawing } \\
\text { from life. }\end{array}$ \\
\hline $\begin{array}{l}\text { The concept of the relationship between } \\
\text { architecture and plastic arts }\end{array}$ & Practical experience \\
\hline
\end{tabular}

To compare the research results, the number of types of practical tasks for both programs was calculated and is presented in the Table 2 . 
Table 2. The number of types of practical tasks for both programs.

\begin{tabular}{|l|l|l|l|}
\hline Task type & $\%$ in programm & Task type & \% in programm \\
\hline $\begin{array}{l}\text { Acquaintance with } \\
\text { architectural } \\
\text { monuments }\end{array}$ & 17 & $\begin{array}{l}\text { Acquaintance with } \\
\text { architectural } \\
\text { monuments }\end{array}$ & 8 \\
\hline Composition & 23 & Composition & 16 \\
\hline Graphic arts & 22 & Graphic arts & 26 \\
\hline Pictorial art & 25 & Pictorial art & 31 \\
\hline Sketches, studies & 13 & Sketches, studies & 16 \\
\hline & & exhibition design & 3 \\
\hline
\end{tabular}

The poll showed that the greatest interest in the first practice was aroused by excursions on architectural objects, in the second - acquaintance with famous artists and masterclasses. Skills were formed in a different sequence. The perception of the architectural and natural form and its use in creating an image occurred in different ways. The methods of work aimed at concretizing one task gave positive results in general visual literacy and freedom of expression of the compositional concept.

As a result of the program's recast become some changes in this context. The more specific the task was, the more interesting and different the results were. The task was divided into stages. The students concentrated all their attention on practicing one skill, after which they moved on to the next task. As a result of consistent mastering, students have thoughtfully treated the task and the learning outcomes were not temporary, but permanent.

\section{Discussion}

Based on these results, it is proposed to build a program and tasks for plein air practice by the main competencies of the architect:

1. Acquaintance with architectural objects. You need to look at them from different points of view, find interesting angles, and notice the lighting conditions in which they are most interesting. This is an interesting stage, combining a walk, excursion, scientific research, and reportage shooting.

2. Sketches and sketches of landscape and architecture in pencil. When the objects are found, it is necessary to make many small pencil sketches and sketches to find interesting compositions. Use various compositional techniques and a different scale of images: closeup - an architectural detail in the environment, medium plan: 3-5 large objects (adjacent buildings, architectural forms of a part of the street, background: street perspective, city panorama.

3. Sketches are performed in fixed graphics - they teach you to be thoughtful and organized, hone your technique.

4. Analysis of the architectural object. Sketching with soft materials - drawing from the stain. The angle from which the compositional structure of the object is most readable is determined. An indispensable condition is the recognition of the object: the transfer of the planning structure of the object, the proportion of the main forms. Black-and-white modeling of the object, elaboration of details, and ornaments is being carried out.

5. Peculiarities of color perception in plein air conditions. The study of the technology of writing with watercolors in a wet manner, in gouache, the technique of color stretch, marks the use of corpus techniques and mixed media.

6. Study for the state: morning, afternoon, and evening. The influence of lighting in natural conditions, the difference in color in sunny and cloudy diffused lighting.

7. A sketch in a limited palette. Evening. The value of tone in painting. 
8. Composition "Multi-faceted urban landscape". Performed in the last days of practice when sufficient material has already been collected to create a composition. Independent creative search for a graphic solution.

Further research is supposed to be devoted to the educational possibilities of conducting the plein air practice in the form of master classes by professional artists.

\section{Conclusion}

Consideration of various programs showed that most universities are unanimous on the question of what competencies of the future architect, laid down in the curriculum can be provided by artistic practice. Universal competencies - Systemic and critical thinking UC-1, Teamwork and leadership UC-3, Self-organization, and self-development UC-6; General professional competencies - Artistic and graphic GPC-1, General engineering GPC-4.

The main objectives of the plein air practice program for students of architectural direction are:

- Consolidation of theoretical knowledge gained during the study of the disciplines "Drawing" and "Painting";

- Knowledge about the methods of visual display and modeling of three-dimensional forms and space, the logic of constructing volumetric spatial forms, the properties of graphic means of expressing architectural design;

- Mastering the means and methods of creative work on composition: the ability to analyze and model various volumes and spaces, both in nature and by presentation;

- Acquisition of practical experience in the use of knowledge, skills, and abilities of graphic representation of architectural objects and their elements, acquisition of knowledge in related areas of professional activity - construction and art history.

The main requirements for the content of the plein air practice program are:

1. Acquaintance with monuments of architectural heritage and plastic arts that complement their image: sculpture, arts and crafts, painting, graphics, and landscape architecture.

2. Creative and research approach to the object of the image, collecting graphic material, preliminary sketches, and sketches from nature.

3. The study of the techniques, technologies, materials of plastic arts, drawing, painting, and composition necessary for the formation of a future professional architect as a competent specialist in this area who can convey his ideas in graphic expression, using the means of related arts to express an architectural project and managing specialists in these areas.

\section{References}

1. N. Zakharova, I. Vlasova, O. Kartavtseva, Technologies of tutorial assistance in the visual activity distance education for the bachelors-designers, In: Innovative Technologies in Science and Education (ITSE-2020), E3S Web of Conferences 210, 22014 (2020) doi: 10.1051/e3sconf/202021022014.

2. N. Zakharova, I. Vlasova, Technological initiative for the "roadmap" implementation for the bachelors-designers' creative development in art, In: Innovative Technologies in Science and Education (ITSE-2020), 22013, E3S Web of Conferences 210, (2020) doi: 10.1051/e3sconf/202021022013.

3. I. Vlasova, Y. Ushanyova, S. Pisarenko, Professional competencies formation in the field of aesthetic artwork evaluation, In: Innovative Technologies in Science and Education (ITSE-2020), E3S Web of Conferences 210, 22027 (2020) doi: $10.1051 / \mathrm{e} 3$ sconf/202021022027. 
4. A.A. Prishchepa, L.A. Burovkina, V.V. Koreshkov, International Journal of Engineering \& Technology 7(4), 393-395 (2018) doi: 10.14419/ijet.v7i4.38.24589.

5. A. Prishchepa, O. Maidibor, The value of ancient architecture for educational program of masters of architectural space design, In: International Science Conference SPbWOSCE-2016 “SMART City”, MATEC Web of Conferences 106, 09014 (2017) doi: 10.1051/matecconf/201710609014.

6. A. Besgen, N. Kuloglu, S. Fathalizadehalemdari, Procedia - Social and Behavioral Sciences 182, 428-432 (2015) doi: 10.1016/j.sbspro.2015.04.813.

7. A. Besgen, Procedia - Social and Behavioral Sciences 182, 420-427 (2015) doi: 10.1016/J.SBSPRO.2015.04.812.

8. P.O. Adewale, O.B. Adhuze, Frontiers of Architectural Research 3(1), 69-75 (2014) doi: 10.1016/j.foar.2013.11.002.

9. A. Torres, J. Serra, J. Llopis, Á. García, N. Cabodevilla, Procedia - Social and Behavioral Sciences 191, 2505-2514 (2015) doi: 10.1016/j.sbspro.2015.04.626.

10. M. Mahdavinejad, R. Bahtooei, S.M. Hosseinikia, M. Bagheri, A.A. Motlagh, F. Farhat, Procedia - Social and Behavioral Sciences 116, 4443-4448 (2014) doi: 10.1016/j.sbspro.2014.01.963.

11. M.A. Yalçın, M. Ulusoy, Procedia - Social and Behavioral Sciences 174, 1820-1828 (2015) doi: 10.1016/j.sbspro.2015.01.843.

12. A. Palea, G. Ciobanu, A. Kilyeni, Procedia - Social and Behavioral Sciences 46, 46724677 (2012) doi: 10.1016/j.sbspro.2012.06.316.

13. A.B. Daemei, H. Safari, Frontiers of Architectural Research. 7(1), 100-106 (2018) doi: 10.1016/j.foar.2017.09.001.

14. G. Swanson, The Journal of Design, Economics, and Innovation 6(1), 101-105 (2020) doi: 10.1016/j.sheji.2020.01.001.

15. H.M. Danaci, Procedia - Social and Behavioral Sciences 174, 1309-1312 (2015) doi: 10.1016/j.sbspro.2015.01.752. 